\title{
Keeping Food Alive: Surplus Food Management
}

\author{
By Sedef Sert ${ }^{1}$, Paola Garrone ${ }^{1}$, Marco Melacini ${ }^{1}$
}

\begin{abstract}
This paper is motivated by the paradoxical reality of food waste in a world of food insecurity, which is an important issue even for developed countries. Today, in Europe, nearly 43.6 million people are estimated to be food insecure, while European countries are reported to generate $179 \mathrm{~kg}$ per capita of food waste every year. Previous empirical studies highlight the potential of surplus food management, i.e. managerial processes and practices that strike a balance between social, environmental and economic goals and avoid safe food that is not sold or consumed degrade into waste. A multidisciplinary literature is reviewed in order to present the current state of art with a special attention on food redistribution for social purposes. In particular, I focus on differences between surplus food and food waste and discuss benefits and costs of surplus food redistribution to the disfavored population.
\end{abstract}

Key Words: food, waste, surplus, recovery, agriculture

\section{Introduction}

Recently, the issue of surplus food management has attracted much attention from academics and practitioners, since it is believed to have a huge possibility to reduce food insecurity, i.e. the condition when the food intake of some household members is reduced and normal eating patterns are disrupted at times due to limited resources (Tarasuk \& Eakin, 2005; Coleman-Jensen, Nord, \& Singh, 2013). Food insecurity and food losses together generate a paradoxical reality; a total of 842 million people worldwide were estimated to be suffering from regularly not getting enough food, while approximately 1.3 billion tons per year food is wasted globally (Hall, et al., 2009; Gustavsson, Cederberg, \& Sonesson, 2011; FAO, 2013).

Food insecurity is a relevant issue even in high-income countries. Today, in Europe, nearly 43.6 million people are estimated to be food insecure (Gentilini, 2013). At the same time, European countries are reported to generate $179 \mathrm{~kg}$ per capita of food waste every year. In other words, 89 million tons per year food is wasted in Europe, approximately $58 \%$ of what is produced by firms in manufacturing, wholesale, retail and food service stages of the food supply chain (O'Connor, 2013). Besides the economic loss for the firms producing food waste, social and environmental losses are also clear especially when the food is edible but for various reasons is not sold to or consumed to the intended customer and eventually becomes waste. 
The aim of this paper is to present the concept of "surplus food" and "surplus food management" by trying to summarize the established results of existing studies and to put forward open questions in order to have different research ideas for future studies. In Section 2, the food waste, food scraps and surplus food concepts are explained. In Section 3, the approach to surplus food management that was recently advocated by some policymakers and scholars is presented. In Section 4, the issue of surplus food redistribution to disfavored population is discussed.

\section{Surplus Food}

In literature, a generally accepted definition of food waste and surplus food does not exist, since it is subject to different interpretations within different perspectives (Garrone, Melacini, \& Perego, 2013). In fact, going back in time, one of the oldest papers found about food waste published in 1979 brings about the debate on the issue of what the food waste is and what food waste is not (Singer, 1979). Most of the studies try to explain the food waste by dividing it into different categories (Kantor, et al., 1997; Kummu, et al., 2012; Beretta, et al., 2013) or directly quantifying the value of waste along the food supply chain (Buzby \& Hyman, 2012; Nahman \& Lange, 2013; Katajajuuri, et al., 2014).

A recently developed conceptual model called "ASRW" gives a clear definition for "surplus food" and distinguishes it from the food waste by introducing the concepts of Availability, Surplus, Recoverability and Waste. According to the model, Food Availability is defined as "all food produced throughout the food supply chain" and it consists of three components: food availability for "human consumption", "surplus food" and "food scraps". Food availability for human consumption includes "the edible food that is delivered through traditional market channels and consumed by people to satisfy their food needs". Surplus food is defined as "the edible food that is produced, manufactured, retailed or served but for various reasons is not sold to or consumed by the intended customer" and food scraps are "inedible food that is no longer suitable for human consumption" (Garrone, Melacini \& Perego, 2014a).

\section{Surplus Food Management}

From agriculture and fishing stage to final household consumption food is wasted throughout the whole supply chain, together with water, cropland and fertilizers used to produce losses (Lunqvist, Fraiture, \& Molden, 2008; Hall, et al., 2009; Kosseva, 2013). Therefore, reducing the food losses along the food supply chain is a critical and high priority component of any sustainability strategy with a high potential to improve (Smil, 2004; Parfitt, Barthel, \& Macnaughton, 2010; Hodges, Buzby, \& Bennett, 2011). According to Food Recovery Hierarchy Process (EPA, 2013), the strategies suggested are source reduction, feeding human, feeding animals, industrial usage, composting and disposal respectively (Figure 1). 


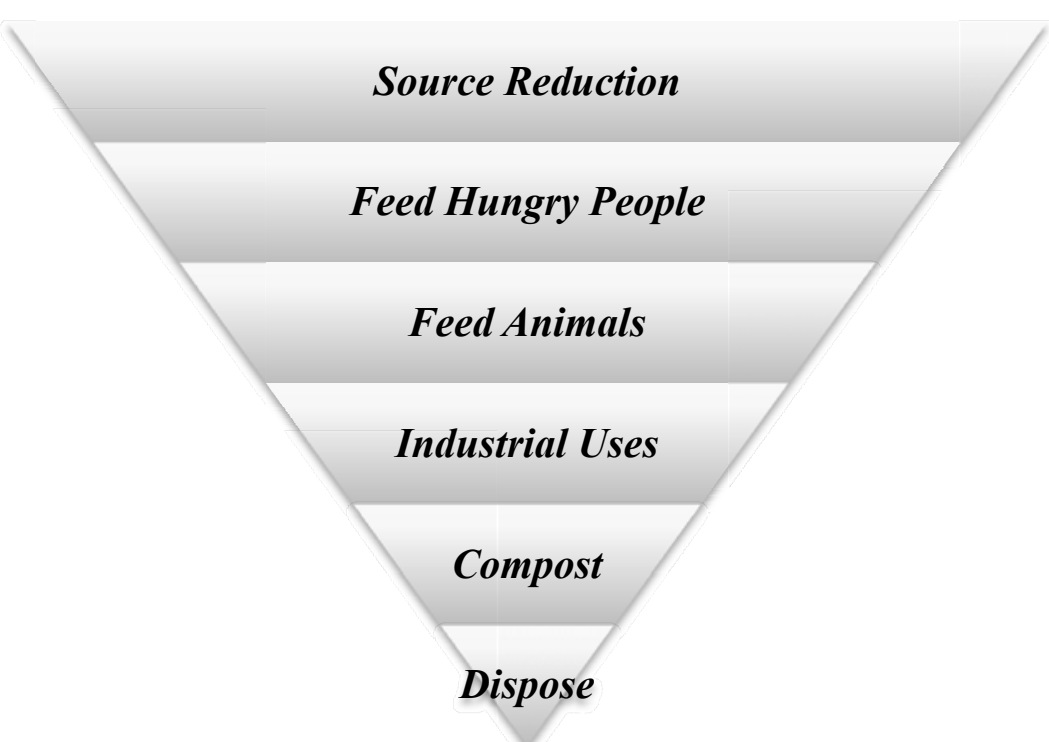

Figure 1 - Food Recovery Hierarchy Process (EPA, 2013)

\section{Source Reduction}

Reducing the volume of food waste generated is the first strategy suggested to food processing companies and the literature on this issue is well constructed in the sustainable supply chain stream. Especially, the growing variety in products, intense competition together with the short lead times of food products require great attention for pursuing a sustainable food supply chain (Minnich \& Maier, 2006; Ahumada \& Villalobos, 2009; Taylor \& Fearne, 2009; Van Donk, 2011; Beske, Land, \& Seuring, 2013). In particular, the short sell by dates limits opportunities to use inventories as a buffer against demand uncertainty in fresh food sector, and consequently the most wasteful products are those with relatively short shelf life (Mena, Diaz, \& Yurt, 2011).

The good practices suggested by the empirical studies include collaboration between the supply chain actors in terms of high information sharing (Mena, Diaz, \& Yurt, 2011; Tupper \& Whitehead, 2011), moving order penetration point close to customer (Kaipia, Popovska, \& Loikkanen, 2012), contemporary modeling and demand planning by simulation and value stream mapping (Darlington \& Rahimifard, 2006), monitoring and measuring of waste flows (Eriksson, Strid, \& Hansson, 2012; Lorton, et al., 2014).

\section{Feeding People and Feeding Animals}

Even if the firms consider all relevant aspects in order to decrease the surplus food generation at source, the surplus food production is inevitable in some cases (Garrone, Melacini, \& Perego, 2014b). Once the surplus food is generated, it has to be managed efficiently and effectively; and donating the extra food to food banks, soup kitchens and shelters is seen as the best practice from economic, from environmental and especially from social perspective (EPA, 2013; Lorton, et al., 2014).

Apart from the surplus food suitable for the human consumption, the food scrap which is edible by the animals is suggested to be diverted to animal feed. Although, in some 
countries the food waste goes to landfill instead of being used as animal feed due to the legislations to control prion diseases, this kind of recovery is applied by many companies (Godfray, 2010; Garrone, Melacini, \& Perego, 2013).

\section{Industrial Uses, Composting Landfill, Incineration and Disposal}

Besides feeding the human and feeding the animal, another way is the reusing, since the food waste residues containing a number of valuable compounds derivable have a great potential to be reused into other production systems (Thassitou \& Arvanitoyannis, 2001; Schieber, Stintzing, \& Carle, 2001; Galanikis, 2012; Mirabella, Castellani, \& Sala, 2014). Otherwise, food waste can be used for fuel conversation and for digestion to recover energy (Hall \& Howe, 2012).

On the other hand, many of the food processing companies use composting as a means of waste management. Composting is the natural aerobic biochemical process in which microorganisms transform organic materials such as waste from vegetables, fruits, fish and meat into stable soil-like product. In addition to economic value of the product, the process is generally perceived as being environmentally friendly (Schaub \& Lonard, 1996; Seadi \& Holm-Nielsen, 2004).

Obviously, sending the valuable materials to landfilling, incineration and disposal is not the ideal situation for the society and economy, and consequently appears at the bottom of the Food Recovery Hierarchy Process (EPA, 2013). Not only from environmental and social point of views but also from financial point of view; landfilling, incineration and disposal are not preferable. Many empirical studies demonstrate that waste reduction improvements lead to substantial financial savings for the companies (Bates \& Phillips, 1999; Hyde et al., 2001; Lundie \& Peters, 2004; Darlington, Staikos, \& Rahimifard, 2009 Levis, et al., 2010).

\section{Surplus Food Redistribution to Disfavored Population}

Although there are some debates on the issue, food assistance through surplus food is considered as a mean to fight against food poverty by many researchers and practitioners (Tarasuk \& Eakin, 2003; Aleksandar \& Smaje, 2008; Foresight, 2011; Hawkes \& Webster, 2014).

First of all, from the sustainability perspective, surplus food redistribution has the most socially prioritized strategy since nothing is wasted and food is used to tackle food security, i.e the highest priority (Schneider, 2013). Moreover, in most countries, tax deductions are granted based on the social return from the donated food, helping to save cost for companies (Aiello, Enea, \& Muriana, 2013). Furthermore and specifically, it has been demonstrated that food donation programs save large companies more than $\$ 100000$ in annual shipping and landfilling cost (Thang, 2009).

Food redistribution strategy is analyzed also from the Corporate Social Reasonability (CSR) perspective, which is a very crucial leverage for global companies receiving great attention from their stakeholders. Dimensions of CSR in the food supply chain can be classified as animal welfare, biotechnology, health and safety, environment, labor and human rights, community, fair trade, and procurement (Maloni \& Brown, 2006). The surplus food redistribution makes contribution to the environment dimension of any 
CSR strategy (Rana, Platts, \& Gregory, 2009; Hartmann, 2011), as well as human rights and community (Gentilini, 2003; Lorton, et al., 2014). Additionally food donations could help improve corporate reputation (Buzby \& Hyman, 2011).

Another interesting stream of the literature focuses on the issue of prosocial behavior, which can be defined as the "voluntary behavior intended to benefit another", such as helping, sharing, donating, co-operating, and volunteering (Brief \& Motowidlo, 1886). Studies show that there is a positive correlation between prosocial activities and employee satisfaction and team performance (Anik, et al., 2009; Aknin, et al., 2011). This appears to be a promising avenue to motivate surplus food redistribution, but there is no study directly addressing the relationship between the prosocial behavior of the donor company employees and the efficiency and effectiveness of surplus food redistribution to needy.

Although surplus food redistribution by the food supply chain players has many advantages for companies like improving corporate image, eliminating disposal costs and tipping fees, there are some legal and "red tape" requirements that the donator has to meet, which can be considered as a barrier for the companies. The attempts by the governments like the Bill Emerson Good Samaritan Food Donation are seen as good practices to facilitate the donation of food and grocery products to social welfare organizations (Schneider, 2013).

\section{Conclusion}

This paper presents the current state of the art on the issue of surplus food management by reviewing both governmental reports and scholarly articles. In particular, focusing on the "surplus food" and its different nature from "food waste", this paper summarizes the opportunities for the recovery of surplus food and the most socially prioritized strategy of food redistribution to the disfavored population by trying to put together different contributions from a very diverse literature.

The negative economic, environmental and social impacts of food waste are studied by many researchers and different kinds of methods are emerged within different contexts. In literature, many references exist for the upstream side of surplus food management, which is trying to find the practices to decrease the surplus food or food scrap generation at source. However, the surplus food generation is inevitable in some circumstances and once it is generated it has to be managed within the responsibility of the companies.

Comparing to other strategies; animal feeding, industrial usage, composting, landfilling, incineration and disposal, it can be said the surplus food redistribution to disfavored population is socially and environmentally superior. However, the economical perspectives for the companies are not studied thoroughly in the literature except for some cases. Nevertheless, as far as the social goal of feeding the poor is concerned, this strategy has to be analyzed in the context of the food policies, which eventually requires further aspects.

Additionally, further research should be directed towards mapping the process of food redistribution, understanding the barriers that the firms have to encounter and the 
drivers that enable firms for donation. The economic advantages and the costs of surplus food redistribution to the disfavored population should be analyzed, focusing on the issue of increasing the food redistribution process efficiency and effectiveness. Other areas of attention could be the role of Corporate Social Responsibility culture of the firms in the food redistribution attitude and impact of prosocial values of the employees in such companies.

\section{Acknowledgement}

I would like to thank all my colleagues from the Foodsaving project.

The Foodsaving Project was funded by the European Commission, Cariplo Foundation and Lombardy Region.

\section{References}

Ahumada, O., \& Villalobos, J. (2009). Application of Planning Models in the Agri-food Supply Chain: A Review. European Journal of Operational Research, 1-20.

Aiello, G., Enea, M., \& Muriana, C. (2013). Economic Benefit from Food Recovery at the Retail Stage: An Application to Italian Food Chains. Waste Management .

Aknin, L., C., B., Dunn, E., Helliwell, J., Biswass, R., Norton, M. (2010). Prosocial Spending and Well-Being: Cross-Cultural Evidence for a Psyscological Universal. Harvard Business School.

Aleksandar, C., \& Smaje, C. (2008). Surplus Food Redistribution: An Analysis of a Third Sector Model. Resource, Conservation and Recycling, 1290-1298.

Anik, L., Aknin, L., Norton, M., \& Dunn, E. (2009). Feeling Good About Giving: The Benefits (and Costs) of SelfInterested Charitable Behaviour. Harvard Business School.

Bates, M., \& Phillips, P. (1999). Sustainable Waste Management in the Food and Drink Industry. British Food Journal, 580-589.

Beretta, C., Stoessel, F., Baier, U., \& Hellweg, S. (2013). Quantifying Food Losses and The Potential for Reduction. Waste Management, 764-773.

Beske, P., Land, A., \& Seuring, S. (2013). Sustainable Suuply Chain Management Practices and Dynamic Capabilities in the Food Industry: A Critical Analysis of the Literature. International Journal of Production Economics.

Brief, A., \& Motowidlo, S. (1886). Prosocial Organizational Behaviours. Academy of Management, 710-725.

Buzby, J. C., \& Hyman, J. (2012). Total and Per Capita Value of Food Loss in the United States. Food Policy, 561-570.

Buzby, J., \& Hyman, J. (2011). The Value of Retail and Consumer Level Fruit and Vegetable Losses in the United States. The Journal of Consumer Affairs, 492-515.

Carter, C., Kale, R., \& Grimm, C. (2000). Environmental Purchasing and Firm Performance: An Empirical Investigation. Transportation Research, Part E, 219-228.

Coleman-Jensen, A., Nord, M., \& Singh, A. (2013). Household Food Security in the United States. Washington, US: United States Department of Agriculture Economic Research Center.

Darlington, R., \& Rahimifard, S. (2006). A Responsive Demand Management Framework for the Minimization of Waste in Convenience Food Manufacture. International Journal of Computer Integrated Manufacturing, 1-22.

Darlington, R., Staikos, T., \& Rahimifard, S. (2009). Analytical Methods for Waste Minimisation in the Convenience Food Industry. Waste Management, 1274-1281.

EPA. (2013). Putting Surplus Food to Good Use. Washington, US: United States Environmental Protection Agency.

Eriksson, M., Strid, I., \& Hansson, P. (2012). Food Losses in siz Swedish Retail Stores: Wastage of Fruit and Vegetables in Relation to Quantities Delivered. Resources, Conservation and Recycling, 14-20.

FAO. (2013). The State of Food Insecurity in the World. Rome, Italy: Food and Agriculture Organization of the United Nations. 
Foresight. (2011). The Future of Food and Farming Final Project Report. London, UK: The Government Office for Science.

Galanikis, C. (2012). Recovery of High Added-value Components from Food Wastes: Conventional, Emerging Technologies and Commercialized Applications. Food Science \& Technology, 68-87.

Garrone, P., Melacini, M., \& Perego, A. (2013). Feed the Hungry: The Potential of Surplus Food Recovery. Milan, Italy: Edizioni AngeloGuerini e Associati SpA.

Garrone, P., Melacini, M., \& Perego, A. (2014a). Opening the Blackbox of Food Waste Reduction. forthcoming Food Policy.

Garrone, P., Melacini, M., \& Perego, A. (2014b). Surplus Food Recovery and Donation: The Upstream Process. forthcoming British Food Journal.

Gentilini, U. (2013). Banking on Food: The State of Food Banks in High-income Countries. Brighton, UK: Institute of Development Studies.

Godfray, H. (2010). Food Security: The Challange of Feeding 9 Billion People. Science.

Gustavsson, J., Cederberg, C., \& Sonesson, U. (2011). Global Food Losses and Food Waste. Rome, Italy: Food and Agriculture Organization of United Nations.

Hall, G., \& Howe, J. (2012). Energy from Waste and the Food Processing Industry. Process Safety and Environmental Protection, 203-212.

Hall, H., Guo, J., Dore, M., \& Chow, C. (2009). The Progressive Increase of Food Waste in America. PlosOne, 1-6.

Hartmann, M. (2011). Corporate Social Responsibility in the Food Sector. European Review of Agricultural Economics, 297-324.

Hawkes, C., \& Webster, J. (2014). Too Much and Too Little? - Debates on Surplus Food Redistribution. Sustain.

Hodges, R., Buzby, J., \& Bennett, B. (2011). Postharvest Losses and Waste in Developed and Less Developed Countries: Opportunities to Improve Resource Use. Journal of Agricultural Science, 37-45.

Hyde, K., Smith, A., Smith, M., \& Henningsson, S. (2001). The Challange of Waste Minimization in the Food and Drink Industry: A Demonstration Project in East Anglia, UK. Journal of Cleaner Production , 57-64.

Kaipia, R., Popovska, I., \& Loikkanen, L. (2012). Creating Sustainable Fresh Food Supply Chains Through Waste Reduction. International Journal of Physical Distribution \& Logistics Management, 262-276.

Kantor, L., Lipton, K., Manchester, A., \& Oliviera, V. (1997). Estimating and Adressing America's Food Losses. Food Review, 2-12.

Katajajuuri, J., Silvennoinen, K., Hartikainen, H., \& Heikkila, L. (2014). Food Waste in the Finnish Food Chain. Journal of Cleaner Production, 1-8.

Kosseva, M. R. (2013). Causes and Challenges of Food Waste. In M. R. Kosseva, \& C. Webb, Food Industry Wastes: Assessment and Recuperation of Commodities (pp. 15 - 24). San Diego, USA: Academic Press, Elsevier.

Kummu, M., De Moel, H., Porkka, M., Siebert, S., Varis, O., \& P.J., W. (2012). Lost Food, Wasted Resources: Global Food Supply Chain Losses and Their Impacts on Freshwater, Cropland, and Fertiliser Use. Science of Total Environment, 477-489.

Levis, J., Barlaz, M., Themelis, N., \& Ulloa, P. (2010). Assessment of the State of Food Waste Treatment in the United States and Canada. Waste Management.

Lorton, C., Fitzgerald, J., Cole, A., McGrath, M., Varney, M., Sarll, R., . . Scott, V. (2014). Food Connection Programme - Final Report. Oxon, UK: WRAP - Waste \& Resources Action Programme.

Lundie, S., \& Peters, G. (2004). Life Cycle Assessment of Food Waste Management Options. Journal of Cleaner Production, 275-286.

Lunqvist, J., Fraiture, C., \& Molden, D. (2008). Saving Water: From Field to Fork - Curbing Losses and Wastage in the Food Chain. Stockholm, Sweden: Stockholm International Water Institute.

Maloni, M., \& Brown, M. (2006). Corporate Social Responsibility in the Supply Chain: An Application in the Food Industry. Journal of Business Ethics, 35-52.

Mena, C., Diaz, B., \& Yurt, O. (2011). The Causes of Food Waste in the Supplier - Retailer Interface: Evidences from the UK and Spain. Resources, Conservation and Recycling, 648-658.

Minnich, D., \& Maier, F. (2006). Supply Chain Responsiveness and Efficiency - Complementing or Contradicting Each Other? International Conference of System Dynamics Society. Nijmegen, Netherlands.

Mirabella, N., Castellani, V., \& Sala, S. (2014). Current Options for the Valorization of Food Manufacturing Waste: A Review . Journal of Cleaner Production, 28-41. 
Nahman, A., \& Lange, W. (2013). Cost of Food Waste Along the Value Chain: Evidence from South Africa. Waste Management, 2493-2500.

O'Connor, C. (2013, June 20). The Organisation for Economic Co-operation and Development (OECD). Retrieved from www.oecd.org

Parfitt, J., Barthel, M., \& Macnaughton, S. (2010). Food Waste within Food Supply Chains: Quantification and Potential for Change to 2050. Philosophical Transactions of the Royal Society, 2065-3081.

Rana, P., Platts, J., \& Gregory, M. (2009). Exploration of Corporate Social Responbility (CSR) in Multinational Companies within the Food Industry. Corporate Sustainabilty Research Conference 2008. Belfast, UK: Queen's University Management School .

Schaub, S., \& Leonard, J. (1996). Composting: An Alternative Waste Management Option for Food Processing Industries. Trends in Food Science \& Technology.

Schieber, A., Stintzing, F., \& Carle, R. (2001). By-products of Plant Food Processing as a Source of Functional Compounds - Recent Developments. Food Science \& Technology, 401-413.

Schneider, F. (2013). The Evolution of Food Donation with respect to Waste Prevention. Waste Management, 755-763.

Seadi, T., \& Holm-Nielsen, J. (2004). Utilization of Waste from Food and Agriculture. Solid Waste: Assessment, Monitoring and Remediation.

Singer, D. D. (1979). Food Losses in the UK. The Nutrition Society, (pp. 181-186). UK.

Smil, V. (2004). Improving Efficiency and Reducing Waste in Our Food System. Environmental Sciences, 17-26.

Tarasuk, V., \& Eakin, J. (2003). Charitable Food Assistance as Symbolic Gesture: An Ethnographic Study of Food Banks in Ontario. Social Science \& Medicine, 1505-1515.

Tarasuk, V., \& Eakin, J. (2005). Food Assistance Through "Surplus" Food: Insights from an Ethnographic Study of Food Bank Work. Agriculture and Human V alues, 177-186.

Taylor, D., \& Fearne, A. (2009). Demand Management in Fresh Food Value Chains: A Framework for Analysis and Improvement. Supply Chain Management: An International Journal, 379 - 392.

Thang, H. (2009). Food Reclamation as an Approach to Hunger and Waste: A Conceptual Analysis of the Charitable Food Sector in Toronto, Ontario. Journal of Hunger and Poverty.

Thassitou, P., \& Arvanitoyannis, I. (2001). Bioremediation: A Novel Approach to Food Waste Management. Food Science \& Technology, 185-196.

Tupper, J., \& Whitehead, P. (2011). Reducing Food Waste through Retail Supply Chain Collaboration. Oxon, UK: WRAP - Waste \& Resources Action Programme.

Van Donk, P. (2011). Make to Stcok or Make to Order: The Decoupling Point in the Food Processing Industry. International Journal of Production Economics, 297-306.

Sedef Sert is a PhD candidate at Politecnico di Milano (Italy) in Department of Management, Economics and Industrial Engineering. She is currently involved in the "Foodsaving Project" supported by European Commission, Cariplo Foundation and Lombardy Region. Her main research interest is sustainable supply chains and in particular surplus food management. 